Original Paper

\title{
Kontribusi Persepsi Siswa Tentang Sekolah Menengah Kejuruan dan Cara Belajar Terhadap Hasil Belajar Siswa Sekolah Menengah Kejuruan (SMK) Negeri 1 Hiliserangkai
}

\author{
Aprianus Telaumbanua ${ }^{1}$
}

${ }^{1}$ (IKIP Gunungsitoli)

*Corresponding Author: Aprianus Telaumbanua, IKIP Gunungsitoli;

Email:

april telaumbanua@yahoo.com

\begin{abstract}
Berdasarkan hasil studi pendahuluan penulis, ternyata hasil belajar siswa SMKN 1 Hiliserangkai masih rendah. Hasil belajar ditentukan banyak faktor, diantaranya adalah persepsi siswa tentang Sekolah Menengah Kejuruan dan cara belajar. Penelitian ini betujuan untuk mengungkap kontribusi persepsi siswa tentang Sekolah Menengah Kejuruan dan cara belajar terhadap hasil belajar siswa SMKN 1 Hiliserangkai. Tiga hipotesis yang diuji dalam penelitian ini, yaitu: (1) persepsi siswa tentang Sekolah Menengah Kejuruan berkontribusi terhadap hasil belajar, (2) cara belajar berkontribusi dengan hasil belajar, (3) persepsi siswa tentang Sekolah Menengah Kejuruan dan cara belajar secara bersama-sama berkontribusi terhadap hasil belajar. Populasi dalam penelitian ini adalah seluruh siswa SMKN 1 Hiliserangkai yang berjumlah 404 orang, dan sampel sebanyak 101 orang diambil dengan menggunakan teknik stratified proposional random sampling. Instrumen yang digunakan untuk pengumpilan data adalah angket model skala Likert yang telah diuji kesahihan dan keandalan. Hasil analisis menunjukkan bahwa: (1) persepsi siswa tentang Sekolah Menengah Kejuruan berkontribusi 11,6\% signifikan terhadap hasil belajar, (2) cara belajar berkontribusi $12,5 \%$ signifikan terhadap hasil belajar, (3) persepsi siswa tentang Sekolah Menengah Kejuruan dan cara belajar secara bersama-sama berkontribusi 12,3\% signifikan terhadap hasil belajar. Berdasarkan temuan ini, dapat disimpulkan bahwa persepsi siswa tentang Sekolah Menengah Kejuruan dan cara belajar adalah dua faktor penting yang berkontribusi terhadap hasil belajar siswa SMKN 1 Hiliserangkai. Oleh karena itu, disarankan kepada pihak-pihak yang terkait untuk dapat memperhatikan kedua faktor ini agar hasil belajar siswa SMKN 1 Hiliserangkai dapat lebih meningkat.
\end{abstract}

Keywords: Persepsi; Cara Belajar; Hasil Belajar

\section{Pendahuluan}

Pemerintah menciptakan kebijaksanaan dalam pendidikan sebagai sarana pengembangan bangsa, meliputi kemanusiaan dan pengembangan Sumber Daya Manusia (SDM) yang berkualitas. Pendidikan yang mampu mendukung pembangunan bangsa dan negara di masa yang akan datang, yang mampu mengembangkan segenap potensi siswa sehingga selaras dengan program pembangunan nasional dalam rangka mencapai tujuan nasional. Pendidikan nasional akan ditingkatkan menuju pengembangan kualitas dan kesepadanan kompetensi dasar dan kejuruan dalam rangka mewujudkan tujuan pembangunan di bidang pendidikan sekaligus mengantisipasi ketidakmampuan menjawab tantangan zaman.

Sekolah Menengah Kejuruan (SMK) salah satu wahana yang tepat sebagai lembaga pendidikan yang menghasilkan tenaga terampil untuk mempersiapkan diri dalam memasuki dunia 
kerja dengan pemenuhan kompetensi diberbagai pengembangan. Sebagaimana tercantum dalam tujuan pendidikan Sekolah Menengah Kejuruan (SMK), yaitu meningkatkan kecerdasan, pengetahuan, kepribadian, akhlak mulia, serta keterampilan untuk hidup mandiri dan mengikuti pendidikan lebih lanjut sesuai dengan kejuruannya (Depdiknas, 2006).

Salah satu masalah yang dihadapi dalam dunia pendidikan dewasa ini, khususnya pendidikan kejuruan menyangkut hasil belajar siswa. Hasil belajar yang dimaksud tentunya hasil belajar yang benar-benar menunjukkan kemampuan siswa sesuai dengan kompetensi yang diharapkan. Hal ini berkaitan dengan program studi/jurusan yang ada. Kemampuan biasanya diukur berdasarkan nilai yang dicapai siswa melalui penilaian (evaluasi) yang dilaksanakan guru.

Dikmenjur (2000) menyatakan bahwa pendidikan umumnya dan pendidikan kejuruan khususnya menghadapi sejumlah masalah antara lain masih rendahnya persepsi dan pemahaman peserta didik akan dunia kerja. Rendahnya pemahaman tersebut mengakibatkan kurangnya cara belajar peserta didik dalam belajar, yang dalam hal ini dapat mengakibatkan rendahnya kualitas hasil belajar yang dicapai peserta didik.

Studi awal yang dilakukan peneliti di SMKN 1 Hiliserangkai, menunjukan beberapa indikasi positif diduga menyebabkan kurang berkualitasnya hasil belajar, yaitu:

menyangkut persepsi siswa terhadap SMK, (2) siswa memasuki sekolah tersebut karena mudah dijangkau, tidak membutuhkan biaya yang besar, (3) belum optimalnya pembinaan dan bimbingan karir yang dilakukan, (4) dari dialog peneliti dengan beberapa orang siswa menuturkan bahwa cara belajar mereka sangat variatif dan kurang berpola, (5) motivasi yang diberikan guru kepada siswa dirasakan belum memberi semangat maksimal serta kurang menumbuhkan kreatifitas-kreatifitas yang berguna.

Berdasarkan uraian di atas, untuk mengkaji lebih jauh masalah ini maka peneliti mengangkat topik penelitian, yaitu "Kontribusi
Persepsi Siswa Tentang Sekolah Menengah Kejuruan Dan Cara Belajar Terhadap Hasil Belajar Siswa Sekolah Menengah Kejuruan (SMK) Negeri 1 Hiliserangkai”.

\section{Metode}

Penelitian ini tergolong dalam penelitian kuantitatif dengan jenis ex-post facto dan menggunakan pendekatan korelatif. Artinya seluruh data penelitian yang terkait dengan persepsi siswa tentang Sekolah Menengah Kejuruan (SMK) dan cara belajar yang memiliki hubungan korelasional. Penelitian ini dilaksanakan di SMKN 1 Hiliserangkai, desa Hilizia kecama Hiliserangkai Kabupaten Nias.

Sugiono (2006) "Variabel merupakan gejala yang menjadi penelitian untuk diamati, variabel itu sebagai atribut dari sekelompok orang atau objek yang mempunyai variabel antara satu dengan yang lainnya dalam kelompok itu". Berdasarkan hal tersebut, maka variabel penelitian ini mencakup dua variabel independen, yaitu: persepsi siswa tentang Sekolah Menengah Kejuruan $\left(\mathrm{X}_{1}\right)$ dan cara belajar siswa $\left(\mathrm{X}_{2}\right)$, sedangkan hasil belajar $(\mathrm{Y})$ merupakan variabel dependen.

Jenis data dalam penelitian adalah data primer dan data skunder. Data primer diperoleh dari hasil angket yang diisi oleh responden, yang mencakup persepsi siswa tentang Sekolah Menengah Kejuruan dan cara belajar siswa, sedangkan data skunder diperoleh dari Daftar Kumpulan Nilai (DKN) siswa SMKN 1 Hiliserangkai.

Instrumen yang digunakan untuk pengumpilan data adalah angket model skala Likert yang telah diuji kesahihan dan keandalan.

\section{Hasil dan Pembahasan Deskripsi Data}

Berdasarkan hasil analisis dengan bantuan Program SPSS 17 secara umum dan kedua variabel bebas, yaitu Persepsi Siswa Tentang Sekolah Menengah Kejuruan $\left(\mathrm{X}_{1}\right)$ dan Cara Belajar $\left(\mathrm{X}_{2}\right)$ dengan variabel terikat yaitu Hasil Belajar (Y), maka diperoleh skor dari masing-masing variabel 
tersebut sebagai kualitatif terhadap instrumen yang telah disebarkan kepada 101 orang responden. Adapun gambaran masing-masing variabel tersebut adalah sebagai berikut:

\section{Persepsi Siswa Tentang Sekolah Menengah Kejuruan $\left(\mathbf{X}_{1}\right)$}

Berdasarkan instrumen persepsi siswa tentang Sekolah Menengah Kejuruan $\left(\mathrm{X}_{1}\right)$ yang butir-butirnya berjumlah 30 butir, maka secara ideal skor minimal yang dapat dicapai adalah 30 dan maksimal 150.

Untuk lebih jelasnya deskripsi data persepsi siswa tentang Sekolah Menengah Kejuruan dapat dilihat pada tabel berikut ini.

Tabel 1 Deskripsi Data Frekuensi Persepsi Siswa tentang SMK $\left(X_{1}\right)$

\begin{tabular}{|l|l|r|}
\hline & & \multicolumn{2}{|c|}{$\begin{array}{c}\text { Persepsi siswa tentang SMK } \\
\left(\mathrm{X}_{1}\right)\end{array}$} \\
\hline $\mathrm{N}$ & Valid & 101 \\
\hline & Missing & 0 \\
\hline Mean & 116.16 \\
\hline Median & 116.00 \\
\hline Mode & 122 \\
\hline Std. Deviation & 14.110 \\
\hline Variance & 199.095 \\
\hline Minimum & 88 \\
\hline Maximum & 153 \\
\hline Sum & 11732 \\
\hline
\end{tabular}

Tabel 1 memperlihatkan bahwa variabel persepsi siswa tentang SMK $\left(\mathrm{X}_{1}\right)$, tersebar antara skor tertinggi pada variabel ini adalah 153 skor terendah adalah 88 dan skor nilai tengah (median) 116; skor rata-rata (mean) 116,16 dan simpangan baku (standar deviasi) adalah 14,110 dan sebaran data sebanyak 101 orang.

Untuk pencapaian skor rata-rata, dimana nilai rata-rata persepsi siswa tentang $\operatorname{SMK}\left(\mathrm{X}_{1}\right)$ berbanding dengan nilai skor maksimal kemudian dikalikan dengan $100 \%$ maka diperoleh nilai adalah $75,92 \%$. Berdasarkan nilai tingkat pencapaian responden ini sejalan dengan pendapat Sudjana (1982) bahwa untuk mengetahui tingkat pencapaian dalam interval 65\%-79\% adalah kategori cukup.

\section{Cara Belajar $\left(\mathrm{X}_{2}\right)$}

Berdasarkan hasil analisis data cara belajar $\left(\mathrm{X}_{2}\right)$ yang butir-butirnya berjumlah 33 butir, maka secara ideal skor minimal yang dapat dicapai adalah 33 dan skor maksimal adalah 165. Untuk lebih jelasnya deskripsi data cara belajar dapat dilihat pada tabel berikut.

\section{Tabel 2 Deskripsi data Frekuensi Cara belajar} $\left(\mathbf{X}_{2}\right)$

\begin{tabular}{|l|l|r|}
\hline & & Cara Belajar $\left(\mathrm{X}_{2}\right)$ \\
\hline $\mathrm{N}$ & Valid & 101 \\
\hline & Missing & 0 \\
\hline Mean & 118.15 \\
\hline Median & 120.00 \\
\hline Mode & 120 \\
\hline Std. Deviation & 15.681 \\
\hline Variance & 245.908 \\
\hline Minimum & 83 \\
\hline Maximum & 147 \\
\hline Sum & 11933 \\
\hline
\end{tabular}

Tabel 2 memperlihatkan bahwa variabel cara belajar $\left(\mathrm{X}_{2}\right)$ tersebut antara skor tertinggi pada variabel ini adalah 147 dan skor terendah adalah 83 dan skor nilai tengah (median) adalah120, skor rata-rata (mean) adalah 118,15 dan simpangan baku (standar deviasi) adalah 15,681 dari sebaran data sebanyak 101 responden.

Untuk mencapaian skor rata-rata, dimana rata-rata cara belajar $\left(\mathrm{X}_{2}\right)$ dibandingkan dengan nilai skor maksimal kemudian dikalikan dengan $100 \%$ maka diperoleh nilai adalah $80,37 \%$. Berdasarkan nilai tingkat pencapain responden ini sejalan dengan pendapat sudjana (1982), bahwa untuk mengetahui tingkat pencapaian dalam interval $80 \%-89 \%$ adalah kategori baik.

\section{Hasil Belajar (Y)}

Berdasarkan hasil analisis data hasil belajar (Y) yang di ambil nilai semester. Untuk lebih jelasnya deskripsi data hasil belajar dapat dilihat pada table berikut.

\section{Tabel 3 Distribusi Frekuensi Variabel Hasil} Belajar (Y)

\begin{tabular}{|l|l|r|}
\hline & & Cara Belajar $\left(\mathrm{X}_{2}\right)$ \\
\hline $\mathrm{N}$ & Valid & 101 \\
\hline
\end{tabular}




\begin{tabular}{|l|r|}
\hline \multicolumn{1}{|c|}{ Missing } & 0 \\
\hline Mean & 70.63 \\
\hline Median & 73.00 \\
\hline Mode & 76 \\
\hline Std. Deviation & 7.021 \\
\hline Variance & 49.294 \\
\hline Minimum & 50 \\
\hline Maximum & 80 \\
\hline Sum & 7134 \\
\hline
\end{tabular}

Tabel 3 memperlihatkan bahwa variabel hasil belajar (Y) tersebut antara skor tertinggi pada variabel ini adalah 81 , dan skor terendah adalah 50 dan skor nilai tengah (median) adalah 73,00, skor rata-rata (mean) adalah 70,63 dan simpangan baku (standar diviasi) adalah 7,021 dari sebaran data sebanyak 101 responden.

Untuk pencapaian skor responden dimana nilai rata-rata hasil belajar $(\mathrm{Y})$ berbanding nilai skor maksimal kemudian dikalikan dengan 100\% maka diperoleh nilai adalah $87,19 \%$ Berdasarkan nilai tingkat pencapaian responden ini sejalan dengan Sudjana (1982) yanag menyatakan bahwa untuk mengetahui tingkat pencapaian dalam interval $80 \%$ $89 \%$ adalah kategori baik.

\section{Uji Normalitas}

Variabel yang akan diuji normalitasnya adalah Persepsi siswa tentang SMK $\left(\mathrm{X}_{1}\right)$, dan Cara belajar $\left(\mathrm{X}_{2}\right)$, dan Hasil belajar $(\mathrm{Y})$. sebagai dasar normal atau tidak normal suatu distribusi data pada setiap variabel digunakan taraf signifikan 5\% $(\mathrm{a}=$ $0,05)$, dengan kriteria jika probabilitas hitung besar dari 0,05 maka data berdistribusi normal.

Hasil perhitungan Uji Normalitas dapat terlihat rangkumannya pada tabel berikut ini.

Tabel 4 Data Penelitian

\begin{tabular}{|c|c|c|c|c|}
\hline \multicolumn{5}{|c|}{ Kolmogorov-Smirnov } \\
\hline Variabel & $\mathrm{K}-\mathrm{S}$ & $\begin{array}{l}\text { Prob. } \\
\text { Hitung }\end{array}$ & Kondisi & Keterangan \\
\hline $\begin{array}{l}\mathrm{X}_{1} \\
\mathrm{X}_{2} \\
{ }_{\mathrm{Y}}\end{array}$ & $\begin{array}{l}1,065 \\
0,886 \\
1,873\end{array}$ & $\begin{array}{l}0,207 \\
0,412 \\
0,072\end{array}$ & $\begin{array}{l}0,207>0,05 \\
0,412>0,05 \\
0,072>0,05\end{array}$ & $\begin{array}{l}\text { Berdistribusi } \\
\text { Normal } \\
\text { Berdistribusi } \\
\text { Normal } \\
\text { Berdistribusi } \\
\text { Normal }\end{array}$ \\
\hline
\end{tabular}

Dari tabel 4 di atas, terlihat bahwa data dari masing-masing variabel penelitian ini ternyata

berdistribusi normal, karena nilai probabilitas hitungan dari masing-masing variabel tersebut besar dari nilai probabilitas yang di pakai yakni 0,05 .

\section{Uji Independensi antar Variabel Bebas}

Uji independen antara variabel bebas yang menggunakan koefisien korelasi berguna untuk melihat antara variabel bebas, yaitu hubungan antara variabel Persepsi Siswa tentang SMK $\left(\mathrm{X}_{1}\right)$ dengan Cara belajar $\left(\mathrm{X}_{2}\right)$. Uji independen antara variabel bebas ini harapkan tidak terjadi tumpang tindih antara variabel bebas tersebut.sebagai dasar ada atau tidaknya hubungan antara variabel bebas dapat dilihat dari kriteria jika probabilitas hitung $<0,05$ maka tidak ada hubungan independen, sehingga setiap variabel berdiri sendiri. Hasil perhitungan Uji independen antara variabel bebas terlihat pada rangkuman tabel berikut ini.

Tabel 5 Rangkuman Analisis Uji Independensi

\begin{tabular}{|c|c|c|c|}
\hline Uraian & $\begin{array}{c}\text { Koefisien } \\
\text { korelasi }\end{array}$ & Prob.hitung & Keterangan \\
\hline $\begin{array}{c}\mathrm{X}_{1} \\
\text { dengan } \\
\mathrm{X}_{2}\end{array}$ & 0,120 & $0,229>0,05$ & independen \\
\hline
\end{tabular}

Dari tabel di atas, dapat dilihat,bahwa nilai probabilitas pada korelasi yang terjadi antara variabel bebas berada di atas 0,05 . Hal ini berarti, bahwa masing-masing variabel bebas berdiri sendiri dan tidak ada hubungan sesama variabel bebas (independen). Dengan demikian seluruh variabel bebas pada penelitian ini adalah independen, sehingga data penelitian ini dapat dianalisis lebih lanjut dengan analisis korelasi.

\section{Pengujian Hipotesis \\ Hipotesis Pertama}

Hipotesis pertama dalam penelitian ini adalah "Terdapat korelasi yang positif antara persepsi siswa tentang SMK dengan hasil belajar siswa SMKN 1 Hiliserangkai".Berdasarkan hasil analisis korelasi dan regresi sederhana antara persepsi siswa tentang SMK $\left(\mathrm{X}_{1}\right)$ dengan hasil belajar (Y). dapat dilihat pada tabel di bawah ini.

Tabel 6 Hasil Analisis Korelasi Sederhana antara Variabel $X_{1}$ dengan $Y$ Memakai Model Summary 


\begin{tabular}{|c|c|c|c|c|}
\hline Model & $\mathrm{R}$ & $\begin{array}{c}\mathrm{R} \\
\text { square }\end{array}$ & $\begin{array}{c}\text { Adjusted } \\
\mathrm{R} \\
\text { Square }\end{array}$ & $\begin{array}{c}\text { Std. Error of } \\
\text { The } \\
\text { Estimate }\end{array}$ \\
\hline 1 & $341^{\mathrm{a}}$ & .166 & .107 & 6.633 \\
\hline
\end{tabular}

Dari model Summary di atas, terdapat tingkat hubungan antara persepsi siswa tentang SMK dengan hasil belajar sebesar nilai (R), yaitu merupakan koefisien korelasi sebesar 0,341 sementara besarnya kekuatan hubungan yang ada $\left(\mathrm{R}^{2}\right)$ atau Koefisien determinan adalah sebesar 0,116 . Artinya persepsi siswa tentang SMK hanya mampu menjelaskan hasil belajar sebesar 11,6\%.

Pada tabel berikut ini menunjukkan hasil analisis regresi sederhan antara variabel $\mathrm{X}_{1}$ dengan Y Memakai Tabel Coefficients.

Tabel 7 Hasil Analisis Regresi Sederhan Antara Variabel $X_{1}$ dengan $Y$ Memakai Tabel Coefficients

\begin{tabular}{|c|l|c|c|c|c|c|}
\hline \multicolumn{2}{|c|}{ Model } & \multicolumn{2}{|c|}{$\begin{array}{c}\text { Unstandardized } \\
\text { Coefficients }\end{array}$} & $\begin{array}{c}\text { Standardized } \\
\text { coefficients }\end{array}$ & $T$ & T \\
\hline \multicolumn{2}{|c|}{} & B & $\begin{array}{c}\text { Std. } \\
\text { Error }\end{array}$ & Beta & & \\
\hline 1 & (constant) & 50.914 & 5.500 & & 9.257 & .000 \\
\hline & $\begin{array}{l}\text { Persepsi } \\
\text { Siswa } \\
\text { tentang } \\
\text { SMK }\end{array}$ & .170 & .047 & .341 & 3.611 &. \\
\hline
\end{tabular}

Dari tabel 7 di atas, dapat dijelaskan bahwa nilai signifikansi sebesar 0,170, konstanta yang terbentuk sebesar 50,914 sedangkan koefisien persamaan regresi yang terbentuk sebesar 0,170 . NiIai signifikansi sebesar 0,000 lebih kecil dan nilai signifikansi Alpha sebesar 0,05, maka Ha diterima. Dengan demikian, dapat dinyatakan bahwa nilai koefisien persamaan regresi yang diperolëh sebesar 0,170 dapat dijadikan sebagai alat prediksi untuk ikut menentukan setiap gejala yang teijadi pada variabel Persepsi Siswa tentang SMK $\left(\mathrm{X}_{1}\right)$, baik itu gejala yang sifatnya korelasi.

Dari penjelasan di atas, diperoleh persamaan regresi sederhana yaitu $\hat{\mathrm{Y}}=\mathrm{a}+\mathrm{bX}_{1} \mathrm{di}$ mana $\mathrm{a}=50.914$ dan $\mathrm{b}=0,170$ sehingga persamaan regresinya adalah $\hat{\mathrm{Y}}=50.914+0,170 \mathrm{X} 1$. Persamaan ini menunjukkan bahwa jika nilai $\mathrm{X}_{1}$ naik satu satuan maka akan di ikuti kenaikan nilai $\hat{Y}$ sebesar $0,170 \times 1$. Sebagai contoh diambil nilai responden 1 untuk variabel Persepsi siswa tentang SMK $\left(\mathrm{X}_{1}\right)$ sebesar 117 , hasil prediksinya menjadi $\hat{Y}$
$=50.914+(0,170 \times 117)=70,804$, maka diperkirakan rata-rata 70,804 peningkatan pada basil belajar untuk setiap kenaikan pada variabel persepsi siswa tentang SMK sebesar 117. Dapat disimpulkan ada korelasi antara $\mathrm{X}_{1}$ dengan $\mathrm{Y}$, dimana $0,000<0,05$ artinya korelasi antara $X_{1}$ dan $Y$ signifikan.

\section{Hipotesis Kedua}

Hipotesis kedua dalam penelitian ini adalah "Terdapat korelasi yang positif antara cara belajar dengan hasil belajar siswa SMKN 1 Hiliserangkai". Berdasarkan hasil analisis korelasi dan regresi sederhana antara Cara belajar $\left(\mathrm{X}_{2}\right)$ dengan hasil belajar (Y).

Tabel 8 Hasil Analisis Korelasi Sederhana antara Variabel $X_{2}$ dengan $Y$ Memakai Model Summary

\begin{tabular}{|c|c|c|c|c|}
\hline $\begin{array}{c}\text { Model } \\
\text { Sig }\end{array}$ & $\mathrm{R}$ & $\begin{array}{c}\mathrm{R} \\
\text { Square }\end{array}$ & $\begin{array}{c}\text { Adjusted R } \\
\text { Square }\end{array}$ & $\begin{array}{c}\text { Std. Error of } \\
\text { the Estimate }\end{array}$ \\
\hline 1 & .259 & .125 & .104 & 6.566 \\
\hline
\end{tabular}

.000

Dari model Summary di atas, terdapat tingkat hubungan antara cara belajar dengan hasil .obelajar siswa SMKN 1 Hiliserangkai sebesar nilai (R) yaitu merupakan koefisien korelasi sebesar 0,259 sementara besarnya kekuatan hubungan yang ada $\left(\mathrm{R}^{2}\right)$ atau Koefisien determinan adalah sebesar 0,125 . Artinya cara belajar hanya mampu menjelaskan hasil belajar sebesar $12,5 \%$.

Pada tabel berikut ini menunjukkan hasil analisis regresi sederhana antara variabel $\mathrm{X}_{2}$ dengan Y memakai model coefficients.

\section{Tabel 9 Hasil Analisis Regresi Sederhana Antara Variabel $X_{2}$ dengan $Y$ Memakai Model Coefficients}

\begin{tabular}{|c|c|c|c|c|c|c|}
\hline & \multirow[t]{2}{*}{ Model } & \multicolumn{2}{|c|}{$\begin{array}{c}\text { Unstandardize } \\
d \\
\text { Coefficients }\end{array}$} & \multirow{2}{*}{$\begin{array}{c}\text { Standardized } \\
\text { Coefficients }\end{array}$} & \multirow[t]{2}{*}{ I } & \multirow[t]{2}{*}{ Sig. } \\
\hline & & B & Std. & & & \\
\hline 1 & (Constant) & 62.199 & 5.294 & & 11.749 & .000 \\
\hline & $\begin{array}{l}\text { Cara } \\
\text { Belajar }\end{array}$ & .071 & .044 & .259 & 1.607 & .035 \\
\hline
\end{tabular}


Dari tabel di atas, dapat dijelaskan bahwa nilai signifikansi sebesar 0,035 , konstanta yang terbentuk sebesar 62.199, sedangkan koefisien persamaan regresi yang terbentuk sebesar 0,071 . Nilai signifikansi sebesar 0,035 lebih kecil dan nilai signifikansi Alpha sebesar 0,05, maka Ha diterima. Dengan demikian, dapat dinyatakan bahwa niiai koefisien persamaan regresi yang diperoleh sebesar 0,071 dapat dijadikan sebagai alat prediksi untuk ikut menentukan setiap gejala yang terjadi pada varaibel cara belajar, baik itu gejala yang sifatnya korelasi.

Dari penjelasan di atas diperoleh persamaan regresi sederhana yaitu $\hat{\mathrm{Y}}=\mathrm{a}+\mathrm{bX} 1$ dimana $\mathrm{a}=$ 62.199 dan $\mathrm{b}=0,071$ sehingga persamaan regresinya adalah' $=62.199+0,071 \mathrm{X}_{2}$. Persamaan mi menunjukkan bahwa jika nilai $\mathrm{X}_{2}$ naik satu satuan maka akan diikuti kenaikan nilai $\hat{\mathrm{Y}}$ sebasar $0,071 \times 1$. Sebagai contoh diambil nilai responden 1 untuk variabel cara belajar $\left(\mathrm{X}_{2}\right)$ sebesar 131 , hasil prediksinya menjadi $\hat{Y}=62.199+(0,071 \times 131)=$ 71,50 maka diperkirakan rata-rata 71,50 peningkatan pada hasil belajar siswa SMKN 1 Hiliserangkai untuk setiap kenaikan pada variabel cara belajar sebesar 131. Dapat disimpulkan ada korelasi antara $\mathrm{X}_{2}$ dengan $\mathrm{Y}$ dimana $0,035<0,05$ artinya korelasi antara $\mathrm{X}_{2}$ dan $\mathrm{Y}$ signifikan.

\section{Hipotesis Ketiga}

Hipotesis ketiga dalam penelitian mi adalah "Terdapat korelasi yang positif antara persepsi siswa tentang SMK dan cara belajar secara bersama-sama dengan hasil belajar siswa SMKN 1 Hiliserangkai".

Tabel 10 Hasil Analisis Korelasi Ganda antara Variabel X1 dan X2 dengan $Y$ Memakai Model Summary

\begin{tabular}{|c|c|c|c|c|}
\hline Model & $\mathrm{R}$ & $\begin{array}{c}\mathrm{R} \\
\text { Square }\end{array}$ & $\begin{array}{c}\text { Adjusted } \\
\text { R Square }\end{array}$ & $\begin{array}{c}\text { Std. Error } \\
\text { of the } \\
\text { Estimate }\end{array}$ \\
\hline 1 & .351 & .123 & .105 & 6.641 \\
\hline
\end{tabular}

Dari tabel di atas, terdapat tingkat hubungan variabel independen terhadap variabel dependen sebesar nilai (R), yaitu merupakan koefisien korelasi sebesar 0,351 sementara besarnya kekuatan hubungan yang ada $\left(\mathrm{R}_{2}\right)$ atau Koefisien determinan adalah sebesar 0,123. Artinya variabel independen atau persepsi siswa tentang
SMK dan cara belajar hanya mampu menjelaskan variabel hasil belajar siswa SMKN 1 Hiliserangkai yaitu sebesar $12,3 \%$ dan masih ada faktor lain yang juga ikut memberikan korelasi dengan perubahan hasil belajar siswa SMKN 1 Hiliserangkai, yang tidak nampak dalam pengujian ini dengan presentase sebesar $12,3 \%$.

Tabel 11 Hasil Analisis Regresi Ganda Antara Variabel $X_{1}$ dan $X_{2}$ dengan $Y$ Memakai Model Coefficients

\begin{tabular}{|c|c|c|c|c|c|c|}
\hline \multicolumn{2}{|c|}{ Model } & \multicolumn{2}{|c|}{$\begin{array}{c}\text { Unstandardized } \\
\text { Coefficients }\end{array}$} & $\begin{array}{c}\text { Standardize } \\
\mathrm{d} \\
\text { Coefficients }\end{array}$ & $\mathrm{t}$ & Sig. \\
\hline \multicolumn{2}{|c|}{} & B. & $\begin{array}{c}\text { Std. } \\
\text { Esror }\end{array}$ & Beta & & \\
\hline 1 & $\begin{array}{l}\text { (Constant) } \\
\begin{array}{l}\text { Persepsi } \\
\text { Siswa } \\
\text { tentang }\end{array}\end{array}$ & 47.534 & 6.718 & & 7.076 & 000 \\
\hline $\begin{array}{c}\text { Cara } \\
\text { Belajar }\end{array}$ & .088 & .042 & .065 & .879 & .022 \\
\hline
\end{tabular}

Dari tabel di atas, dapat dijelaskan bahwa nilai konstanta yang terbentuk sebesar 47.534, sedangkan koefisien persamaan bidang regresi variabel Persepsi Siswa tentang SMK $\left(\mathrm{X}_{1}\right)$ sebesar 0,160 dan variabel Cara belajar $\left(\mathrm{X}_{2}\right)$ sebesar 0,088. Taraf signifikansi Alpha 0,05 yaitu sebesar 0,001 untuk variabel Persepsi Siswa tentang SMK $\left(X_{1}\right)$ kedua variabel ini terlihat lebih kecil dan taraf signifikansi dan 0,022 untuk variabel Cara belajar $\left(\mathrm{X}_{2}\right)$ kedua variabel ini terlihat lebih kecil dari taraf signifikansi, maka Ha ditenima. Dengan demikian, dapat dinyatakan bahwa nilai koefisien persamaan bidang regresi yang dibentuk dapat dipakai sebagai alat prediksi untuk ikut menentukan setiap gejala yang terjadi pada variabel Persepsi Siswa tentang SMK $\left(\mathrm{X}_{1}\right)$ dan pada variabel Cara belajar $\left(\mathrm{X}_{2}\right)$ tidak dapat dipakal sebagai alat prediksi untuk ikut menentukan setiap gejala yang terjadi secara bersama-sama dengan hasil belajar siswa SMKN 1 Hiliserangkai.

Dari penjelasan di atas, diperoleh persamaan regresi sederhana yaitu $\hat{Y}=a+b_{1} X$, $\mathrm{b}_{2} \mathrm{X}_{2}$ di mana $\mathrm{a}=47.534$ dan $\mathrm{b}_{1}=0,160$ dan $\mathrm{b}_{2}=$ 0,088 , sehingga persamaan regresi ganda adalah $\hat{Y}$ $=47.534+\mathrm{O}, 160 \mathrm{X}_{1}+0,088 \mathrm{X}$. Persamaan ini menunjukkan bahwa jika nilai variabel Persepsi Siswa tentang SMK $\left(\mathrm{X}_{1}\right)$ dan variabel Cara belajar 
$\left(\mathrm{X}_{2}\right)$ naik satu satuan maka akan di ikuti kenaikan nilai $\hat{Y}$ sebesar $0,160 \mathrm{X}_{1}+0,088 \mathrm{X}_{2}$. Sebagai contoh diambil nilai responden 1 untuk variabel Persepsi Siswa tentang SMK (Xi) sebesar 117 dan variabel Cara belajar $\left(\mathrm{X}_{2}\right)$ sebesar 131 , hasil prediksinya menjadi $\hat{\mathrm{Y}}=47.534+(0,160 \times 117)+(\mathrm{O}, 088 \mathrm{x}$ $131)=77,782$ maka diperkirakan rata-rata 77,782 peningkatan pada hasil belajar siswa SMKN 1 Hiliserangkai untuk setiap kenaikan pada variabel Persepsi Siswa tentang SMK sebesar 117 dan variabel Cara belajar sebesar 131 .

\section{Pembahasan}

Kontribusi Persepsi Siswa tentang Sekolah Menengah Kejuruan $\left(\mathbf{X}_{1}\right)$ Terhadap Hasil Belajar Siswa SMKN 1 Hiliserangkai

Berdasarkan hasil analisis data diperoleh tingkat pencapaian skor variabel Persepsi Siswa tentang Sekolah Menengah Kejuruan termasuk dalam kategori baik, dimana tingkat pencapaian skornya adalah $75,92 \%$, hal ini sejalan dengan pendapat Sudjana (1982), bahwa tingkat pencapaian dalam interval $65 \%-79 \%$ adalah kategori cukup.

Hasil analisis yang menjelaskan bahwa hipotesis persepsi siswa tentang Sekolab Menengah Kejuruan berkontribusi terhadap hasil belajar. Dari hasil analisis diperoleh koefisien korelasi antara persepsi siswa tentang Sekolah Menengah Kejuruan dengan hasil belajar $\left(\mathrm{rx}_{1} \mathrm{y}\right)$ adalah 0,341 yang berarti semakin tinggi persepsi siswa tentang Sekolah Menengah Kejuruan maka semakin tinggi hasil belajar yang diperolehnya. Berdasarkan nilai dari koefisien korelasi yang diperoleh tersebut, maka dapat disimpulkan, bahwa persepsi siswa tentang Sekolah Menengah Kejuruan berkontribusi signifikan terhadap hasil belajar siswa. Kemudian kontribusi yang terjadi antara persepsi siswa tentang Sekolah Menengah Kejuruan dengan basil belajar siswa diperoleh sebesar $11,6 \%$.

Temuan penelitian yang menunjukkan bahwa hasil belajar siswa salah satunya diprediksi berhubungan dengan persepsi siswa didukung oleh berbagai pendapat ahli diantaranya oleh Wortman, (1999), terdefinisikan persepsi sebagai suatu proses di mana otak menginterprestasi sensasi yang diterimanya, memberikan perintah dan makna. Sensasi di sini maksudnya adalah prosés dimana rangsangan dan sel penerima di dalam tubuh mengirim impuls saraf ke otak yang muncul dalam bentuk sentuhan, suara, rasa, percikan, warna, dan lain-lain. Persepsi yang dirangsang oleh keadaan luar siswa yang baik terhadap pendidikan yang ditempuhnya akan menimbulkan sikap positif yang akan berdampak pada hasil belajar siswa.

$$
\text { Walaupun berdasarkan temuan }
$$

menunjukkan bahwa persepsi siswa tentang Sekolah Menengah Kejuruan berkontribusi terhadap hasil belajar. Hal ini terkait pencapaian responden pada variabel ini yang berada pada kategori baik. Artinya pesepsi siswa tentang Sekolah Menengah Kejuruan masih bervariasi. Keadaan ini mungkin disebabkan karena memang Sekolah Menengah Kejuruan masih dipandang sebagai sekolah alternatif. Ada anggapan bahwa siswa yang tidak mampu, baik dalam hal finansial mampu kecerdasannya kurang memilih Sekolah Menengah Kejuruan sekaligus untuk memudahkan mendapat pekerjaan. Anggapan ini menjadi Sekolah Menengah Kejuruan masih dipandang sebelah mata, sehingga sedikit banyak mempengaruhi persepsi siswa tentang Sekolah Menengah Kejuruan.

\section{Kontribusi Cara Belajar $\left(\mathrm{X}_{2}\right)$ Terhadap Hasil Belajar Siswa SMKN 1 Hiliserangkai}

Hasil analisis hipotesis kedua, diperoleh bahwa cara belajar berkontribusi terhadap hasil belajar. dimana tingkat pencapaian skornya adalah $80,37 \%$ termasuk kategori baik, sehingga diperoleh derajat koefesien korelasi antara cara belalar dengan hasil belajar $\left(\mathrm{rx}_{2} \mathrm{y}\right)$ adalah 0,259 yang berarti semakin baik cara belajar yang diperoleh siswa maka semakin tinggi hasil belajar siswa tersebut. Dari hasil analisis diperoleh derajat koefisien korelasi antara cara belajar berkontribusi terhadap hasil belajar siswa SMKN 1 Hiliserangkai $\left(\mathrm{rx}_{2} \mathrm{y}\right)$ adalah 0,259 . Berdasarkan nilai dan koefisien korelasi yang diperoleh tersebut, maka dapat disimpulkan bahwa cara belajar berkontribusi terhadap hasil belalar siswa SMKN 1 Hiliserangkai. Kemudian kontribusi yang terjadi antara cara belajar berkontiibusi terhadap basil belajar siswa SMKN 1 Hiliserangkai diperoleh sebesar 12,5\%

Berdasarkan hasil analisis di atas, berarti cara belajar dipengaruhi juga terhadap hasil belajar siswa, karena semakin baik cara belajar yang akan mereka dapatkan maka hasil belajarnya juga akan meningkat. Penelitian ini membuktikan pendapat para ahli bahwa hasil belajar siswa terkait dengan cara belajar mereka sangat dipengaruhi oleh aspekaspek kepribadian seseorang (aspek internal dan 
eksternal) yang meliputi aspek kognitif, afektif dan psikomotorik. Pada aspek kognitif mencakup pengetahuan dan kemahiran intelektual. Aspek efektif mencakup perasaan, minat, motivasi, sikap, kehendak dan nilai. Sementara aspek pesikomotorik mencakup pengamatan dan gerak-gerak motorik (Winkel, 1996:61).

Cara belajar tidak semata-mata warisan dari dalam diri seseorang, tetapi juga melainkan sangat ditentukan oleh lingkungan, yang dimaksud di sini adalah bagaimana sesorang siswa menyerap informasi dengan mudah lalu mengatur dan mengolah informasi tersebut. Bobbi de Porter, (1999). Langkah penting yang dapat membantu siswa dalam belajar antara lain dengan cara: (1) membaca bahan ajar, (2) membuat catatan, (3) menyelesaikan tugas, (4) antusias dalam belajar. Misalnya untuk dapat nilai yang baik dan tinggi pada pelajaran matematika, cara belajar yang diperlukan adalah dengan selalu melakukan pengulangan dan latihan terhadap materi yang diberikan. Sedangkan menurut Winarno Surakhmad (1980) bahwa seorang siswa sebaiknya perlu mengetahui cara belajar yang efisien seperti mengikuti pelajaran, mempelajari buku-buku yang berhubungan dengan pelajaran dan memanfaatkan perpustakaan, membuat kesimpulan-kesimpulan serta cara mengahadapi ujian.

Pada bagian lain Porter dan Hernacki (2000) juga mengatakan bahwa cara belajar yang dilakukan seseorang merupakan kombinasi tiga faktor yaitu bagaimana orang tersebut menyerap, lalu mengatur dan mengolah informasi yang diterimanya. Agar seseorang dapat mengoptimalkan ketiga faktor itu, dia harus menyadari betul bagaimana gaya belajar yang dimilikinya, agar dia dapat menyerap informasi belajarnya dengan mudah. Pendapat para ahli ini menunjukan pentingnya memiliki cara belajar yang baik sesuai dengan keadaan siswa masing-masing. Semakin baik cara belajar yang dimiliki siswa kecenderungan untuk mendapatkan hasil belajar yang baik menjadi lebih baik.

\section{Kontribusi Persepsi Siswa tentang Sekolah Menengah Kejuruan $\left(X_{1}\right)$ dan Cara Belajar $\left(X_{2}\right)$ Secara Bersama-sama Terhadap Hasil Belajar Siswa SMKN 1 Hiliserangkai.}

Selanjutnya pada hipotesis ketiga persepsi siswa tentang Sekolah Menengah Kejuruan dan cara belajar secara bersama-sama berkontribusi terhadap hasil belajar siswa. Berdasarkan hasil analisis data diperoleh tingkat pencapaian skor variabel persepsi siswa tentang Sekolah Menengah Kejuruan dan cara belajar secara bersama-sama terhadap hasil belajar siswa termasuk dalam kategori baik, dimana tingkat pencapaian skornya sebesar $87,19 \%$.

Hasil analisis hipotesis ketiga ditemukan bahwa derajat koefisien korelasi ganda antara persepsi siswa tentang Sekolah Menengah Kejuruan dan cara belajar secara bersama-sama terhadap basil belajar siswa $\left(\operatorname{Ryx}_{1 \cdot 2}\right)$ sebesar 0,351 yang berarti semakin baik persepsi siswa tentang Sekolah Menengah Kejuruan dan cara belajar secara bersama-sama, maka semakin baik pula hasil belajar yang mereka capai. Kemudian kontribusi yang teiadi antara persepsi siswa tentang Sekolah Menengah Kejuruan dan cara belajar secara bersama-sama berkontribusi terhadap hasil belajar siswa diperoleh sebesar $12,3 \%$.

Berdasarkan nilai dari koefisien korelasi ganda yang dibentuk tersebut, maka dapat disimpulkan bahwa persepsi siswa tentang Sekolah Menengah Kejuruan dan cara belajar secara bersama-sama berkorelasi signifikan terhadap basil belajar siswa.

\section{Kesimpulan}

Berdasarkan data dari hasil analisis yang telah dipaparkan dapat ditarik kesimpulan sebagai berikut :

1. Kontribusi Persepsi siswa tentang Sekolah Menengah Kejuruan terhadap hasil belajar siswa memiliki hubungan yang positif dan signifikan dengan hasil belajar. Hal ini menunjukkan bahwa semakin baik persepsi siswa tentang Sekolah Menengah Kejuruan maka akan semakin baik hasil belajar siswa.

2. Cara belajar memberi kontribusi terhadap hasil belajar siswa, faktor cara belajar berkontribusi signifikan terhadap basil belajar. Artinya cara belajar memberi sumbangan dalam peningkatan hasil belajar siswa.

3. Persepsi siswa tentang Pendidikan Kejuruan dan cara belajar memberi kontribusi secara bersama-sama terhadap hasil belajar siswa. Hasil belajar siswa SMKN 1 Hiliserangkai termasuk dalam kategori baik. Ini berarti persepsi siswa tentang Sekolah Menengah Kejuruan dan cara belajar merupakan prediktor terhadap hasil belajar siswa. 


\section{Ucapan Terima Kasih}

Penulis mengucapkan terima kasih kepada IKIP Gunungsitoli yang telah memberi dukungan financial terhadap penelitian ini.

\section{Daftar Pustaka}

Bloom, B.S. 1998, Taxonomy of Educational Objectives, New York, David Mackay,

Cochran, W.G. 1997, Sampling Techniques, and Edition. New York, John Willey, and sons Ine.

Dasru1,2001, "Kontribusi Tentang Persepsi dan Masa Kerja Terhadap Kinerja Guru Madrasyah Tsanawiyah Negeri Kota Padang". Tesis yang tidak diterbitkan.

Davies, Ivor, K, 1991, Pengelolaan Belajar Mengajar. Jakarta, Rineka Cipta. Depdikbud, 1999, Kurikulum SMK Edisi 1999, Jakarta, Dikmenjur

Depdiknas, 2000, Kerangka Dasar Sistem Pelaksanaan Pendidikan Menengah Kejuruan. Jakarta.

2003, Kurikulum LIK 2004, Jakarta, Dikmenjur. . 2004, Penilaian Hasil Belajar Peserta Didik Sekolah Menengah Kejuruan. Jakarta, Dikmenjur.

De Porter, Bobbi \& Hernacki, Mike, 2000, Quantum Learning, Terjemahan Alwiyah Abdurrahman, Bandung, KAIFA.

2000, Quantum Teaching, Terjemahan Ary Nilandari, Bandung, KAIFA.

Gagne, Robert, M Dan Leslie, J Briggs. 1977. Principles of Instructional Design. New York, Holt Rinehart and Winston.

Gay, L. R and Air Asian, 2000. Educational Research, Competencies for analysis \& Application, Columbus, Ohio, Charles E. Merril Publishing Company.
H.A.R Tilaar, 1993, Kekuasaan Dan Pendidikan, Suatu Tinjauan dari Perspektif Studi Kultur, Magelang, Indonesia Sejahtera.

Hussein, 2000, Pengantar Statistik Pendidikan, Jakarta, Gramedia.

Indra Jati Sidi. 2003. Kebijakan Pendidikan Kejuruan di Indonesia Menjelang Milinium Ketiga. Makalah disampaikan dalm Seminar Nasional dan Temu Karya XI Forum Komunikasi FPTK/JPTK Universitas Se-Indonesia, Jakarta.

Lea bit, Harold, J, 1986, Psikologi Management. (terj. Dra. Mullica Zakardi), Jakarta, Penerbit Erlangga.

Mallows, Abraham, 1970, Motivation and Personality. New York, Naver and Row.

Romizowski, AJ. 1981, Designing International System., New York, Nicolas Publishing Company.

Sadiman Arief. S, 2005, Media Pendidikan: Pengertian, Pengembangan, dan Pemanfaatan, Jakarta, PT. Raja Grafindo Persada.

Schippers, Uwe dan Djajang MP, 1994, Pendidikan Kejuruan di Indonesia, Bandung, Angkasa.

Snelbacker, Glenn E, 1974, Learning Theory, Instructional Theory and Psycoeducation Design, New York, Mc Graw Hill Book Company.

Surya Brata, 1997, Proses Belajar Mengajar di Sekolah, Jakarta, Rineka Cipta.

Suryadi Ace dan Tilaar, 1993, Analisis Kebijakan Pendidikan, Bandung, Remaja Rosda Karya.

Sutrisno Hadi, 1981, Metodologi Riset, Yogyakarta, Andi Offset.

Syaiful Bahri, Djamarah, 2004, Strategi Belajar Mengajar, Rineka Cipta, Jakarta.

Syamsudin Abin, 1986, Psikologi Pendidikan, Bandung, Publikasi Jurusan PBB FIP IKIP.

Tuckman, BW, 1972, Conducting Educational Research,New York, Harcourt Braes Jovanovich, In. 